\title{
Analisis Parameter Fisik-Kimia Air Sungai Kadia pada Tahun Pertama Pandemi COVID-19 di Kota Kendari
}

\author{
Sumarlin $^{1}$, Suherman $^{2}$, Moch. Assidieq ${ }^{3}$ \\ ${ }^{1,2,3}$ Prodi Teknik Lingkungan, Fakultas Teknik, Universitas Muhammadiyah Kendari \\ *Koresponden email: sumarlin@ umkendari.ac.id
}

Diterima: 2 Agustus 2021

Disetujui: 10 Agustus 2021

\begin{abstract}
The high risk of the Coronavirus pandemic (COVID-19) has prompted the government to adopt a variety of policies to limit citizen mobility. The imposition of this mobility restriction has important consequences for the environment. This study analyzes several physical-chemical parameters of the waters of the Kadia River during the first year of the COVID-19 pandemic. The results of this study indicate that temperature, turbidity, DO at low tide and BOD exceed the required quality standard. The contribution of household domestic waste is very likely to have a significant impact on the height of some of these parameters, because in the first year, people are more active at home (working from home). The other parameters (DHL, $\mathrm{pH}, \mathrm{NO} 2, \mathrm{PO} 4)$ are still in the threshold of the quality standard . Therefore, it is necessary to monitor and manage wastewater from urban households so that the sustainability of river ecosystems to continue in the future.
\end{abstract}

Keywords: COVID-19, parameter, physic-chemical, Kadia River, Kendari

\begin{abstract}
Abstrak
Tingginya risiko pandemik Corona virus disease (COVID-19) menyebabkan pemerintah menetapkan sejumlah kebijakan untuk membatasi mobilitas masyarakat. Pemberlakuan pembatasan mobilitas ini berpengaruh signifikan pada lingkungan. Penelitian ini bertujuan untuk menganalisis beberapa parameter fisik-kimia pada air Sungai Kadia di masa tahun pertama pandemik COVID-19. Hasil penelitian ini menunjukkan suhu, turbiditas, DO saat air surut dan BOD melampaui ambang baku mutu yang telah disyaratkan. Kontribusi limbah domestik rumah tangga sangat berpengaruh pada tingginya beberapa parameter ini, karena pada tahun pertama masyarakat lebih banyak beraktivitas di rumah. Adapun parameter lainnya (DHL, $\mathrm{pH}, \mathrm{NO}_{2}, \mathrm{PO}_{4}$ ) masih dalam taraf ambang baku mutu. Oleh karena itu diperlukan upaya pengendalian dan pengelolaan air limbah dari domestik perkotaan agar kelestarian ekosistem sungai dapat berlanjut dimasa mendatang.
\end{abstract}

Kata Kunci: COVID-19, parameter, fisika-kimia, Sungai Kadia, Kendari

\section{Pendahuluan}

Penyebaran Corona virus disease (COVID-19) yang telah mengglobal menimbulkan berbagai ragam persoalan, bukan hanya permasalahan kesehatan semata tetapi juga mempengaruhi masalah sosial ekonomi dan lingkungan. Sejak teridentifikasi di Kota Wuhan pada 31 bulan Desember 2019 sampai saat ini per 18 Juli 2021, jumlah kasus COVID-19 telah mencapai 190.169.833 kasus dan jumlah kematian mencapai 4.086.000 kasus [1]. Selain itu, COVID-19 telah bermutasi dan membentuk beberapa varian. Kasus varian Alpha ditemukan di 180 negara, varian Betha 130 negara, varian Gamma 78 negara, varian Delta 124 negara. Sementara itu, pada skala nasional, per 23 Juli 2021 terkonfirmasi positif COVID-19 sebanyak 3.033.339 kasus, sebanyak 2.392.923 sembuh dan sebanyak 79.032 meninggal [2]. Tingginya angka kematian ini menyebabkan pemerintah menetapkan berbagai kebijakan untuk mengurangi mobilitas masyarakat karena pada prinsipnya proses penularan COVID-19 melalui kontak dari orang ke orang [3]. Konsekuensi dari pembatasan mobilitas dan lockdown tersebut membawa bagi lingkungan di berbagai tempat, misalnya tingginya kejernihan air di Laguna Venesia, Italia[4], menurunnya konsentrasi material partikulat tersuspensi danau Vembanad di India [5], menurunnya konsentrasi BOD, COD dan arsenik di Sungai Gangga India[6] dan berkurangnya nilai risiko karsinogenik pada air Sungai Meric-Ergene, Turki [7].

COVID-19 juga telah menyebar di Kota Kendari sejak temukan kasus pertama tanggal 9 Maret 2020 [8]. Saat ini di Kendari tercatat 1.116 kasus positif, 5.489 sembuh dan 83 dinyatakan meninggal [9]. Kota Kendari merupakan kota yang terletak di pesisir Teluk Kendari, Sulawesi Tenggara. Terdapat beberapa sungai yang membela Kota Kendari, salah satunya Sungai Kadia. Sungai Kadia bermuara di Sungai 
Wanggu selanjutnya menuju Teluk Kendari. Penggunaan lahan sepanjang aliran Sungai Kadia digunakan sebagai pertokoan, pasar buah, pergudangan dan pemukiman penduduk. Populasi penduduk yang padat, pengembangan lahan, dan industrialisasi menghasilkan sejumlah limbah organik dan anorganik sehingga mencemari badan air[10]. Bangunan pemukiman maupun pertokoan di bantaran Sungai Kadia dirancang membelakangi sungai untuk mempermudah mengalirkan air sisa kegiatan mandi cuci kakus (MCK) dan limbah domestik lainnya. Air limbah domestik dari aktivitas manusia memberikan kontribusi peningkatan kosentrasi biological oxygen demand (BOD) dan chemical oxygen demand (COD) pada aliran sungai [11].

Tercemarnya air sungai dari aktivitas antropogenik tersebut dapat mendatangkan masalah kesehatan yang serius seperti gatal-gatal, diare dan gangguan penyakit bawaan lainnya. Selain itu, kontaminasi air limbah pada aliran sungai menjadi media penyebaran virus enteric (adenovirus, aichivirus, astrovirus, cosavirus, enterovirus, virus hepatitis A dan E, norovirus dari genogrup I dan II, rotavirus A dan salivirus) sebagai penyebab penyakit akut [12]. Semakin buruk kualitas air sungai maka ancaman kelimpahan bakteri pathogen dan antibiotik pada air sungai akan semakin besar. Untuk itulah, penelitian ini bertujuan menganalisis beberapa parameter fisik-kimia (Suhu, DHL, Turbiditas, DO, $\mathrm{pH}, \mathrm{NO}_{2}, \mathrm{PO}_{4}, \mathrm{BOD}$ ) air Sungai Kadia pada tahun pertama masa Pandemi COVID-19 di Kota Kendari.

\section{Metode Penelitian}

\section{Tempat dan Waktu Penelitian}

Penelitian dilakukan pada perairan Sungai Kadia, Kecamatan Kadia, Kota Kendari. Analisis Laboratorium dilakukan di Laboratorium Teknik Lingkungan, Universitas Muhammadiyah Kendari dan UPTD Balai Laboratorium Dinas Kesehatan Provinsi Sulawesi Tenggara. Adapun waktu penelitian dilaksanakan pada bulan Mei 2020 sampai bulan Juli 2021.

\section{Alat dan Bahan}

Alat-alat yang digunakan dalam penelitian ini adalah Global Positioning System (GPS), botol sampel, wadah penyimpanan sampel (cooling box), thermometer, DO meter, $\mathrm{pH}$ meter sedangkan bahan yang digunakan adalah sampel air sungai sebanyak 1 liter/titik pengamatan

\section{Prosedur Kerja}

Prosedur kerja yang dilakukan dalam penelitian ini mengacu pada [13], sebagai berikut:

1. Menentukan titik-titik pengambilan sampel dengan membagi beberapa segmen yang diharapkan dapat mewakili populasi. Dalam penelitian ini diambil 3 titik pada aliran Sungai Kadia yaitu titik I: hulu sungai ( -3057'52,613" LS, 122028'21,964”), titik II: tengah sungai (-3058'18,699” LS, 122029'34,121”), titik III: hilir sungai (3059'4,956” LS, 122031,969”)

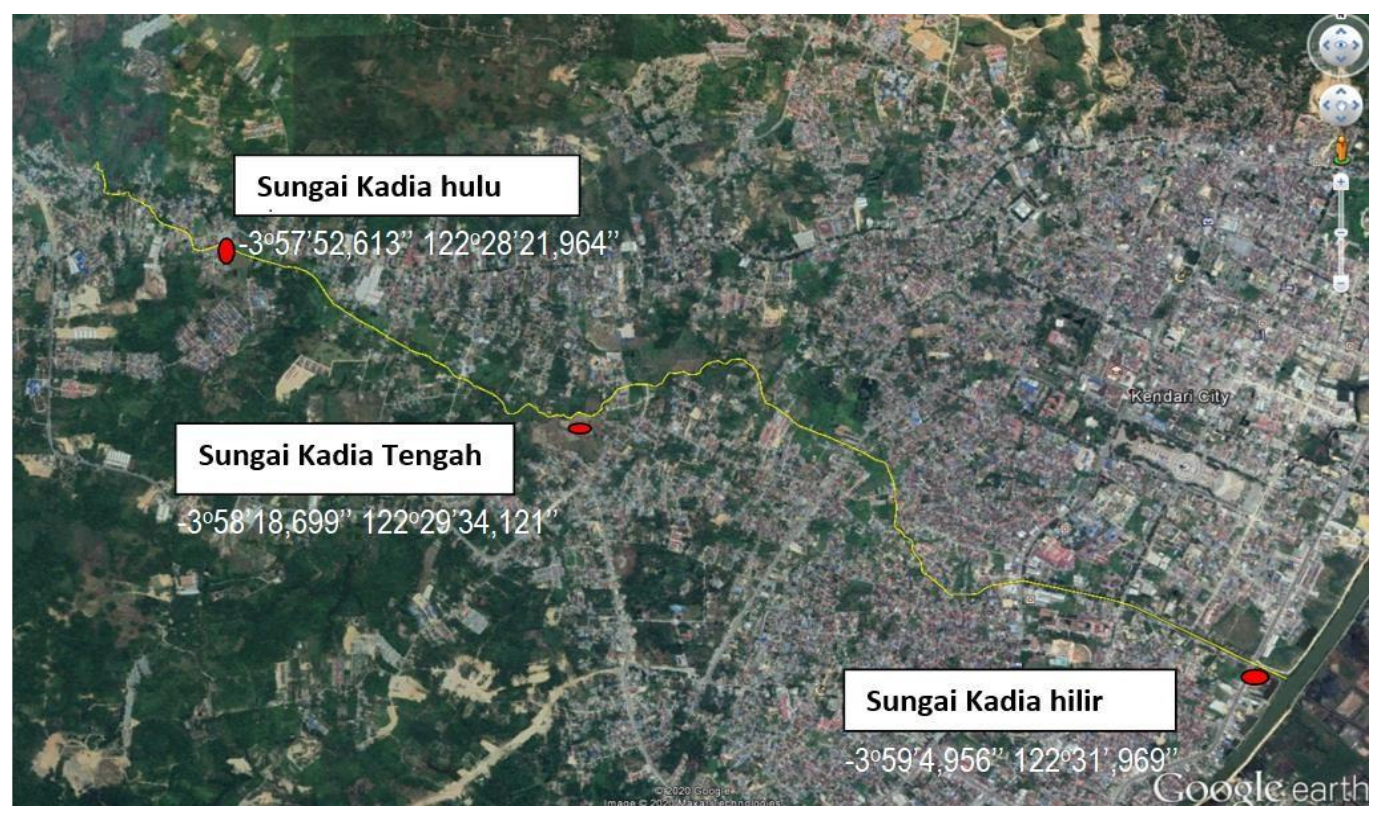

Gambar 1. Lokasi penelitian

Sumber: Hasil analisis, 2021

2. Menyiapkan peralatan dan bahan

3. Pengambilan sampel air sungai, dengan langka-langka sebagai berikut: 
a. Menyiapkan alat pengambilan sampel yang relevan dengan kondisi sungai

b. Membilas alat pengambilan sampel dengan air bersih sebanyak 3 (tiga) kali

c. Mengambil sampel sesuai dengan peruntukan analisis, campurkan dalam penampung sementara kemudian dihomogenkan

d. Memasukan ke dalam wadah yang sesuai peruntukan analisis

4. Menguji dan mengalisis parameter suhu, kekeruhan, daya hantar listrik, pH di titik pengamatan langsung di lapangan (in situ)

5. Hasil pengujian parameter lapangan dicacat, dan dokumentasikan

6. Pengambilan sampel untuk parameter pengujian di laboratorium dan dilakukan pengawetan

7. Menguji dan menganalisis Biological Oxigen Demand $(B O D)$, Fosfat $\left(\mathrm{PO}_{4}\right)$, Nitrat $\left(\mathrm{NO}_{3}\right)$ di laboratorium

\section{Hasil dan Pembahasan}

\section{Parameter Suhu, Daya Hantar Listrik, Turbiditas, DO, dan pH Air Sungai Kadia}

Parameter yang diuji langsung di lapangan (in situ) pada 3 (tiga) titik: T1 (Sungai Kadia Hulu), T2 (sungai Kadia Tengah), T3 (Sungai Kadia Hilir saat pasang), T4 (Sungai Kadia Hilir saat surut) dalam dalam penelitian ini meliputi: parameter suhu (temperatur), daya hantar listrik (DLH), kekeruhan (turbiditas), oksigen terlarut (dissolved oxygen/DO), derajat keasaman $(\mathrm{pH})$. Hasil uji in situ parameter air Sungai Kadia tertera pada Tabel 1.

Tabel 1. Parameter suhu, daya hantar listrik, turbiditas, DO, dan $\mathrm{pH}$ air Sungai Kadia

\begin{tabular}{lllcccc}
\hline \multirow{2}{*}{ No } & \multicolumn{1}{c}{ Titik Pengamatan } & $\begin{array}{c}\text { Suhu } \\
\left({ }^{\circ} \mathrm{C}\right)\end{array}$ & $\begin{array}{c}\text { DHL } \\
(\mu \mathrm{mhos} / \mathrm{cm})\end{array}$ & $\begin{array}{c}\text { Turbiditas } \\
(\mathrm{NTU})\end{array}$ & $\begin{array}{c}\text { DO } \\
(\mathrm{mg} / \mathrm{L})\end{array}$ & $\mathrm{pH}$ \\
\hline 1. & Sungai Kadia Hulu (T1) & 36,2 & 6,95 & 69,9 & 0,11 & 5,86 \\
2. & Sungai Kadia Tengah (T2) & 29,5 & 2,51 & 87,6 & 0,17 & 5,53 \\
3. & Sungai Kadia Hilir Pasang (T3) & 29,4 & 2,43 & 99,6 & 0,21 & 5,39 \\
4. & Sungai Kadia Hilir Surut (T4) & 24,9 & 4,68 & 0,55 & 70,3 & 5,83 \\
\hline \multicolumn{5}{c}{ Sumber: Hasil analisis, 2021} \\
\end{tabular}

Berdasarkan Tabel 1, nilai suhu (temperatur) pada air Sungai Kadia pada titik T1 sebesar $36,2{ }^{\circ} \mathrm{C}$, titik T2 sebesar $29,5^{\circ} \mathrm{C}$, titik T3 sebesar $29,4^{\circ} \mathrm{C}$, dan titik T4 sebesar $24,9^{\circ} \mathrm{C}$. Hal ini menunjukkan semakin ke arah hilir temperatur air sungai semakin menurun. Suhu (temperatur) berkaitan erat dengan kemampuan air dalam menjerap oksigen dari udara sehingga mikroba dapat mendekomposisi bahan organik[14]. Sementara itu ambang baku mutu menurut [15] mensyaratkan deviasi 3 yaitu $\pm 3{ }^{0} \mathrm{C}$ dari suhu normal air alamiah $25^{\circ} \mathrm{C}$ berarti berkisar $22^{\circ} \mathrm{C}-28^{\circ} \mathrm{C}$. Suhu air Sungai Kadia berkisar $24,9^{\circ} \mathrm{C}-36^{\circ} \mathrm{C}$, ini mengindikasikan suhu air sungai Kadia tidak dapat menunjang berlangsungnya ekosistem di perairan sungai, sebagaimana terlihat dalam Gambar 2. Secara umum, kisaran temperatur yang optimal untuk kehidupan fitoplankon di perairan berkisar $20^{\circ}-30^{\circ}$ [16]

Pada pengamatan daya hantar listrik (DLH) pada air Sungai Kadia pada titik T1 sebesar 6,95 pada titik T1 sebesar 6,95 $\mu \mathrm{mhos} / \mathrm{cm}$, titik T2 sebesar 2,51 $\mu$ mhos $/ \mathrm{cm}$, titik T3 sebesar 2,43 $\mu$ mhos $/ \mathrm{cm}$ dan titik T4 sebesar 4,68 $\mu \mathrm{mhos} / \mathrm{cm}$. Daya hantar listrik (DLH) pada Sungai Kadia mengalami fluktuasi. DHL tertinggi terjadi pada titik T1 dan DLH terendah pada titik T3. Fluktuasi DLH ini disebabkan oleh kondisi saat pengambilan sampel. DHL tinggi berarti saat pengambilan sampel air kondisi perairan sedang dalam keadaan keruh yang mengindikasikan banyaknya senyawa organik atau ion-ion lain yang dapat menghantarkan listrik. Adapun nilai DHL rendah berarti pengambilan sampel air dalam kondisi perairan sedang jernih atau tidak keruh. DLH dapat dilihat pada Gambar 3.

Kekeruhan (turbiditas) air menjadi salah satu parameter untuk menentukan kualitas air, lihat Gambar 4. Hasil analisis kekeruhan pada air Sungai Kadia menunjukkan bahwa, nilai kekeruhan pada titik T1 sebesar 69,9 NTU, titik T2 sebesar 87,6 NTU, titik T3 sebesar 99,6 NTU, dan titik T4 sebesar 0,55 NTU. Nilai kekeruhan pada titik T3 lebih besar daripada titik lainnya. Tingginya kekeruhan air Sungai Kadia ini disinyalir pada waktu pagi hari masyarakat banyak yang melakukan pembuangan limbah cair/padat, pembuangan sampah organik dan anorganik ke aliran sungai, dan lain sebagainya. Hal ini mengakibatkan terjadinya perubahan warna alamiah air sungai, (kekuning- kuningan), kotor, berbau serta terjadinya kekeruhan. Selain itu kekeruhan air sungai juga disebabkan oleh menumpuknya bahan organik yang berasal dari aktivitas perumahan dan industri di sekitar bantaran sungai. Buangan limbah domestik dan non domestik dapat juga meningkatkan parameter air sungai yang lain yaitu oksigen terlarut (dissolved oxygen/ DO). 


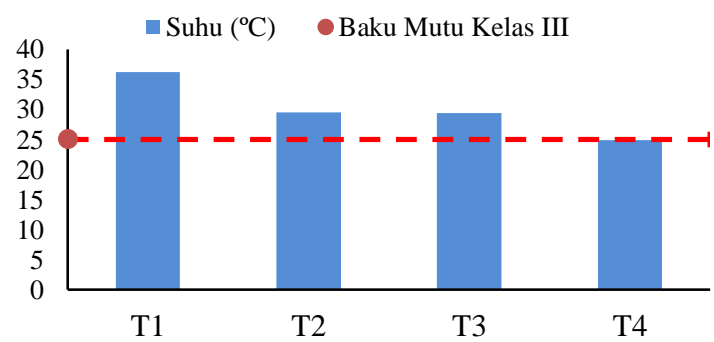

Gambar 2. Keadaan Suhu Air Sungai Kadia

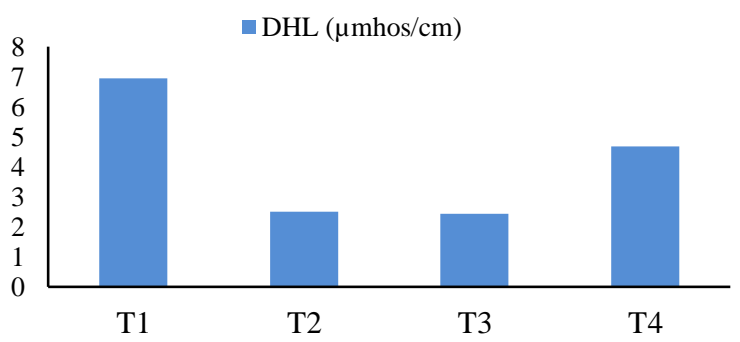

Gambar 3. Daya Hantar Listrik Air Sungai Kadia

Sumber: Hasil penelitian, 2021

Pada pengamatan oksigen terlarut (dissolved oxygen/DO) pada air sungai Kadia menunjukkan nilai DO pada titik T1 sebesar 0,11 mg/L, titik T2 sebesar 0,17 mg/L, titik T3 sebesar 0,21 mg/L dan titik T4 sebesar 70,3 mg/L (Gambar 5). Nilai DO mengalami peningkatan secara signifikan pada titik T4 disebabkan karena pada titik ini merupakan bagian hilir sungai dan kebolehjadian sungai telah tercemar oleh akumulasi hasil buangan limbah domestik dan non domestik.

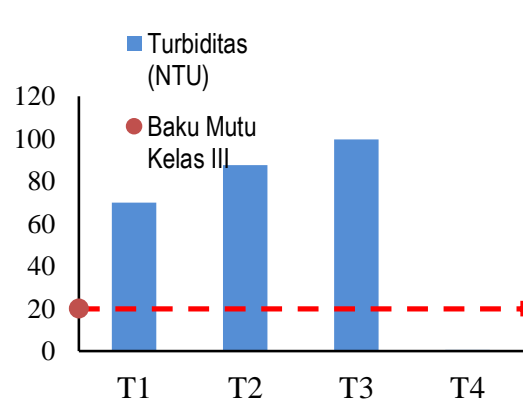

Gambar 4. Keadaan Turbiditas Air Sungai Kadia

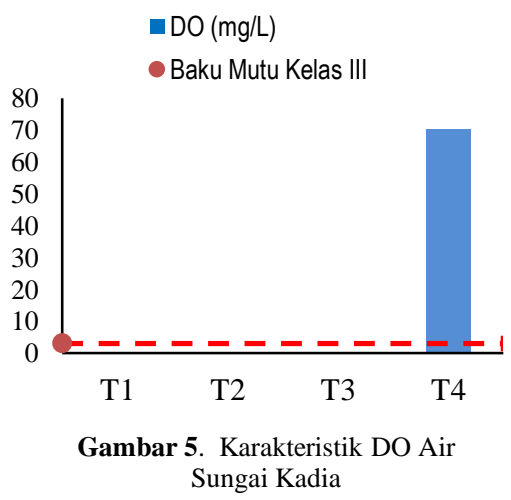

Sumber: Hasil penelitian, 2021

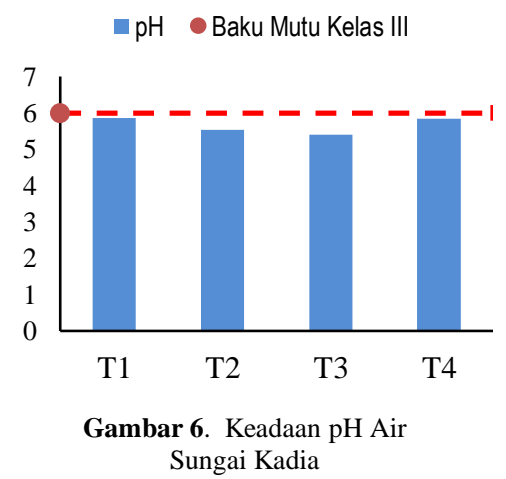

Limbah organik dan anorganik yang dibuang ke dalam aliran sungai mempengaruhi peningkatan derajat keasaman [17]. Air dengan nilai pH normal sekitar 6,5 -7,5 dapat memenuhi syarat untuk kehidupan. Hasil analisis $\mathrm{pH}$ pada air sungai Kadia menunjukkan nilai $\mathrm{pH}$ pada titik $\mathrm{T} 1$ sebesar 5,86, titik T2 sebesar 5,53, titik T3 sebesar 0,21 dan titik T4 sebesar 5,83. Nilai pH meningkat pada titik T1, nilai pH berkisar antara 5,0-6,0 (Gambar 6). Limbah yang dibuang tidak bersifat asam atau basa dalam kadar yang tinggi, namun lebih bersifat organik yang dapat terurai baik secara biologis maupun kimiawi di badan air. Air bersifat asam memiliki $\mathrm{pH}$ kurang dari 7 dan bersifat air basa lebih dari 7. Peningkatan nilai derajad $\mathrm{pH}$ dipengaruhi oleh limbah organik maupun anorganik yang di buang ke sungai.

Parameter Nitrat $\left(\mathrm{NO}_{2}\right)$, Phosphat $\left(\mathrm{PO}_{4}\right)$ dan Biological Oxigen Demand (BOD) Air Sungai Kadia

Sampel air sungai untuk menguji parameter Nitrat $\left(\mathrm{NO}_{2}\right)$, Phosphat $\left(\mathrm{PO}_{4}\right)$ dan Biological Oxigen Demand (BOD) diambil pada 3 (titik) yang berbeda yaitu hulu Sungai Kadia (T1), tengah Sungai Kadia (T2) dan hilir Sungai Kadia kondisi pasang (T3) dan surut (T4). Alat (wadah) yang digunakan untuk menampung sampel air sungai adalah botol ukuran 1 liter. Sementara, ukuran kedalaman dan waktu pengambilan sampel, bervariasi. Adapun kedalaman dan waktu pengambilan sampel pada titik T1 $(0,30$ meter; pukul 10:00 WITA); T2 (0,40 meter; pukul 13:00 WITA); T3 (0,15 meter; pukul 15:00 WITA saat air pasang), T4 (0,70 meter; pukul 08:00 WITA saat air surut).

Berdasarkan hasil uji laboratorium menunjukkan bahwa kandungan parameter $\mathrm{BOD}, \mathrm{NO}_{3}$ dan $\mathrm{PO}_{4}$ di Sungai Kadia pada tiap titik cukup bervariasi. Kandungan parameter BOD pada titik T1 sebesar 12,80 $\mathrm{mg} / \mathrm{L}$, titik T2 sebesar 28,20 mg/L, titik T3 sebesar 10,50 mg/L dan titik T4 sebesar 32,50 mg/L. Kandungan $\mathrm{NO}_{3}$ pada titik T1 sebesar 1,41 mg/L, titik T2 sebesar 1,62 mg/L, titik T3 sebesar 1,89 mg/L dan titik T4 
sebesar 1,57 mg/L. Sedangkan kandungan $\mathrm{PO}_{4}$ pada titik T1 sebesar 0,026 mg/L, titik T2 sebesar 0,112 $\mathrm{mg} / \mathrm{L}$, titik T3 sebesar 0,018 $\mathrm{mg} / \mathrm{L}$ dan titik T4 sebesar 0,175 mg/L. Hasil uji laboratorium parameter air sungai kadia tertera pada Tabel 2.

Tabel 2. Parameter BOD, $\mathrm{NO}_{3}$ dan $\mathrm{PO}_{4}$ air Sungai Kadia

\begin{tabular}{|c|c|c|c|c|c|c|}
\hline \multirow{2}{*}{ No } & \multirow{2}{*}{ Titik Pengamatan } & \multirow{2}{*}{ Kedalaman (m) } & \multicolumn{3}{|c|}{ Parameter } & \multirow[b]{2}{*}{ Satuan } \\
\hline & & & BOD & $\mathrm{NO} 3$ & PO4 & \\
\hline 1. & Sungai Kadia Hulu (T1) & 0,3 & 12,8 & 1,41 & 0,026 & $\mathrm{mg} / \mathrm{L}$ \\
\hline 2. & Sungai Kadia Tengah (T2) & 0,4 & 28,2 & 1,62 & 0,112 & $\mathrm{mg} / \mathrm{L}$ \\
\hline 3. & Sungai Kadia Hilir Pasang (T3) & 1,5 & 10,5 & 1,89 & 0,018 & $\mathrm{mg} / \mathrm{L}$ \\
\hline 4. & Sungai Kadia Hilir Surut (T4) & 0,7 & 32,5 & 1,57 & 0,175 & $\mathrm{mg} / \mathrm{L}$ \\
\hline & Baku Mutu Kelas III & & 6 & 20 & 1 & $\mathrm{mg} / \mathrm{L}$ \\
\hline
\end{tabular}

Sumber: Hasil penelitian, 2021

Berdasarkan Tabel 2 menunjukkan bahwa kandungan parameter BOD, $\mathrm{NO}_{3}$ dan $\mathrm{PO}_{4}$ di Sungai Kadia bervariasi pada tiap titiknya. Jika dibandingkan dengan baku mutu berdasarkan [15], [18] dengan batas maksimum kandungan BOD sebesar $6 \mathrm{mg} / \mathrm{L}$ (Kelas III $\mathrm{NO}_{3}$ sebesar $20 \mathrm{mg} / \mathrm{L}$ (Kelas III) dan $\mathrm{PO}_{4}$ sebesar $1 \mathrm{mg} / \mathrm{L}$ (Kelas III). Nilai BOD pada titik T1, T2, T3 dan T4 berada dikisaran 10-33 mg/L, ini artinya Sungai Kadia dikategorikan tercemar karena nilai BOD sudah melebihi baku mutu dengan nilai yang sangat signifikan. Limbah domestik berkontribusi pada peningkatan BOD perairan sungai[11]. Nilai $\mathrm{NO}_{3}$ pada titik T1, T2, T3 dan T4 berada dikisaran 1-2 mg/L, hal ini mengindikasikan bahwa nilai ini masih dibawah baku mutu dan dikategorikan belum tercemar. Nitrat di perairan merupakan makro nutrien yang mengendalikan produktivitas primer di daerah eufotik.

Kadar nitrat di perairan hilir dipengaruhi oleh asupan dari badan sungai yang bersumber dari buangan rumah tangga, kotoran hewan dan manusia serta pertanian[19]. Adapun nilai $\mathrm{PO}_{4}$ pada titik T1, T2, T3 dan T4 berada dikisaran 0,010-1,200 mg/L telah melebihi baku mutu yang ditetapkan. Meskipun nilai $\mathrm{NO}_{3}$ masih dibawah baku mutu, tetapi BOD dan $\mathrm{PO}_{4}$ berdasarkan kategori pencemaran air sungai sudah melebihi baku mutu dengan nilai yang sangat signifikan tentu hal tersebut tidak sesuai untuk kehidupan organisme perairan. Grafik perbandingan parameter $\mathrm{BOD}, \mathrm{NO}_{3}$ dan $\mathrm{PO}_{4}$ di Sungai Kadia dengan baku mutu dapat dilihat pada Gambar 7, Gambar 8, dan Gambar 9.

$\square$ BOD Baku Mutu Kelas III

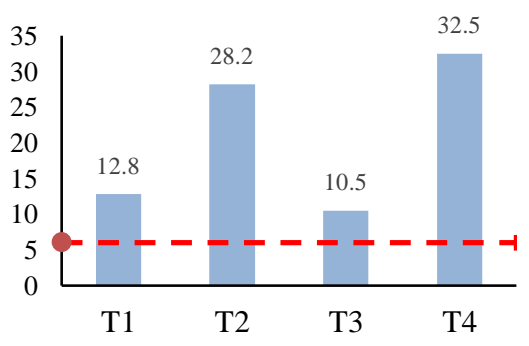

Gambar 7. Parameter BOD Air Sungai Kadia
NO3 Baku Mutu Kelas III

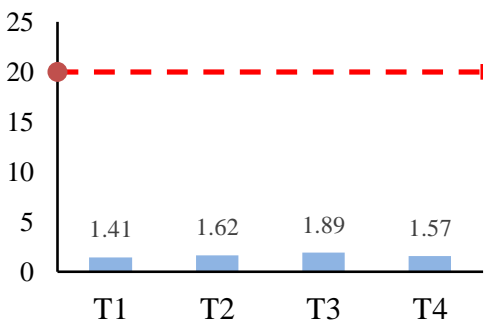

Gambar 8. Parameter $\mathrm{NO}_{3} \mathrm{Air}$ Sungai Kadia
- PO4 Baku Mutu Kelas III

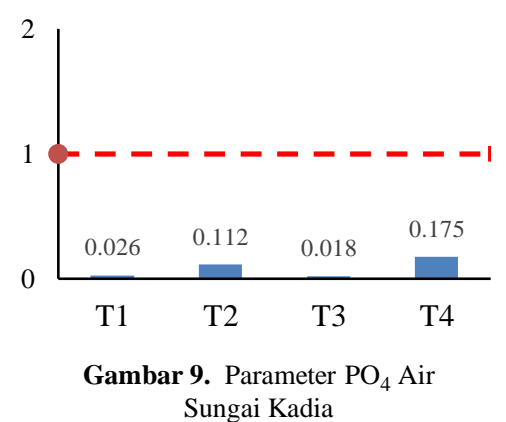

Sumber: Hasil penelitian, 2021

Pada tiap titik pengambilan sampel tingkat pencemaran Sungai Kadia bervariasi. Salah satu penyebabnya karena penggunaan lahan dan aktivitas sepanjang aliran Sungai Kadia juga cukup beragam, diantaranya terdapat pertokoan, pasar buah, pergudangan, dan juga pemukiman yang cukup padat. Dengan demikian limbah yang dihasilkan cukup beragam. Tingkat pencemaran paling tinggi terdapat di bagian hilir sungai sedangkan tingkat pencemaran paling rendah terdapat di bagian hulu sungai Kadia. Peningkatan parameter fisik kimia seperti BOD, DO dan parameter lainnya tidak lain disebabkan oleh akumulasi limbah kegiatan perkotaan (limbah domestik, limbah aktivitas pasar, pertanian, dan industri dan kegiatan antropogenik lainnya di sepanjang daerah aliran sungai [20].

Aktivitas masyarakat di sekitar daerah aliran sungai (DAS) menjadi penyebab tingginya tingkat pencemaran dan menimbulkan vektor penyakit bawaan. Oleh karena itu diperlukan upaya pengendalian dan pengelolaan air limbah domestik agar fungsi ekosistem tidak hilang sebagaimana mestinya [21] dengan demikian, kelestarian fungsi air sungai dapat berlanjut dimasa mendatang. 


\section{Kesimpulan}

Penelitian ini menganalisis beberapa parameter fisik-kimia (Suhu, DHL, Turbiditas, DO, $\mathrm{pH}, \mathrm{NO}_{2}$, $\mathrm{PO}_{4}$, BOD) air Sungai Kadia pada tahun pertama pandemi COVID-19 melalui metode pengujian langsung (in situ) dan pengujian laboratorium. Hasil penelitian ini menunjukkan parameter suhu, turbiditas, DO, BOD melewati ambang baku mutu yang disyaratkan dalam PP No.81 Tahun 2001 dan PP No. 22 tahun 2021. Tingginya parameter-parameter tersebut pada Sungai Kadia tahun pertama masa pandemik COVID19 ini disinyalir dipengaruhi banyaknya limbah domestik rumah tangga yang masuk di aliran sungai karena sebagian besar masyarakat beraktivitas di rumah masing-masing. Adapun parameter lainnya DLH, pH, $\mathrm{NO}_{3}, \mathrm{PO}_{4}$ yang diuji dan analisis dalam penelitian ini belum melewati ambang baku mutu. Perlu penelitian lebih lanjut untuk membandingkan nilai parameter fisik-kimia sebelum, dan setelah setahun lebih pandemik COVID-19 ini.

\section{Ucapan Terimaksih}

Terimakasih kepada Lembaga Penelitian dan Pengabdian Masyarakat Universitas Muhammadiyah Kendari atas kerjasama yang baik selama berlangsungnya penelitian ini.

\section{Singkatan}

$\begin{array}{ll}\text { COVID-19 } & \text { Corona Virus Disease 2019 } \\ \text { UPTD } & \text { Unit Pelaksana Teknis Daerah } \\ \text { BOD } & \text { Biological Oxygen Demand } \\ \text { COD } & \text { Chemical Oxygen Demand } \\ \text { PO }_{4} & \text { Phospate } \\ \text { DO } & \text { Dissolved oxygen } \\ \mathrm{NO}_{3} & \text { Nitrate }\end{array}$

\section{Referensi}

[1] WHO. (2021). COVID-19 Weekly Epidemiological Update. https://www.who.int/publications/m/item/weekly-epidemiological-update-on-covid-19, diakses tanggal 27 Juli 2021.

[2] KPCPEN. (2021). Data Sebaran. https://covid19.go.id/, diakses: tanggal 27 Juli 2021.

[3] Li, Q., X. Guan, P. Wu, X. Wang., L. Zhou. (2020). Early Transmission Dynamics in Wuhan, China, of Novel Coronavirus-Infected Pneumonia. N. Engl. J. Med., 382 (13), 1199-1207, doi: 10.1056/NEJMoa2001316.

[4] Braga. F., G. M. Scarpa, V. E. Brando, G. Manfe., and L. Zaggia. (2020). COVID-19 lockdown measures reveal human impact on water transparency in the Venice Lagoon. Sci. Total Environ., 736, 139612, doi: 10.1016/j.scitotenv.2020.139612.

[5] Yunus, A.P., Y. Masago, and Y. Hijioka (2020). COVID-19 and surface water quality: Improved lake water quality during the lockdown. Sci. Total Environ., 731, 139012, doi: 10.1016/j.scitotenv.2020.139012.

[6] Duttagupta, S., S.N. Bhanja., A. Dutta., S. Sarkar., M. Chakraborty. (2021). Impact of Covid-19 Lockdown on Availability of Drinking Water in the Arsenic-Affected Ganges River Basin. Int. J. Environ. Res. Public. Health, 18 (6), 2832, doi: 10.3390/ijerph18062832.

[7] Tokatli. C., and M. Varol. (2021). Impact of the COVID-19 lockdown period on surface water quality in the Meriç-Ergene River Basin, Northwest Turkey. Environ. Res.,197, 111051, 1-8, doi: https://doi.org/10.1016/j.envres.2021.111051.

[8] Persada. S. (2021). Kisah Pasien Covid-19 Pertama di Kendari yang Sembuh, Tempo, Jakarta, https: //nasional.tempo.co/read/1329785/kisah-pasien-covid-19-pertama-di-kendari-yang-sembuh. diakses 27 Juli 2021

[9] Diskominfo Kota Kendari. (2021). Update Covid-19 Kota Kendari. https://www.kendarikota.go.id/berita/update-covid-19-kota-kendari-selasa-27-juli-2021/. diakses 27 Juli 2021

[10] Kamble, S.M. (2014). Water Pollution and Public Health Issues in Kolhapur City in Maharashtra. International Journal of Scientific and Research Publications, 4 (1), 6.

[11] Arum, S. P. I., and D. Harisuseno. (2019). Domestic Wastewater Contribution to Water Quality of Brantas River at Dinoyo Urban Village, Malang City. J-PAL,10 (2), 8. doi: 10.21776/ub.jpal.2019.010.02.02. 
[12] Prevost, B., F. S. Lucas., A. Goncalves., F. Richard., and S. Wurtzer (2015). Large scale survey of enteric viruses in river and waste water underlines the health status of the local population," Environ. Int., 79, 42-50. doi: 10.1016/j.envint.2015.03.004.

[13] Badan Standardisasi Nasional. (2008). Standar Nasional Indonesia (SNI) 989.59:2008. Air dan air limbah (metoda pengambilan contoh air limbah). PU Cipta Karya. http://ciptakarya.pu.go.id/plp/upload/peraturan/SNI_-6989-59-2008-_Metoda-Pengambilan-ContohAir-Limbah. diakses: 27 Juli 2021

[14] Effendi. H., Romanto, and Y. Wardiatno. (2015). Water Quality Status of Ciambulawung River, Banten Province, Based on Pollution Index and NSF-WQI. Procedia Environ. Sci., 24, 228-237, doi: 10.1016/j.proenv.2015.03.030.

[15] Pemerintah Pusat. (2001). Salinan Peraturan Pemerintah (PP) No. 82 Tahun 2001 Tentang Pengelolaan Kualitas Air Dan Pengendalian Pencemaran Air. Jakarta: Kementerian Sekretariat Negara Republik Indonesia Deputi Perundang-undangan dan Administrasi Hukum.

[16] Effendi, H. (2003). Telaah Kualitas Air: Bagi Pengelolaan Sumber Daya dan Lingkungan Perairan. Yogyakarta: Kanisus.

[17] Ikhsan, A., A. Auliya, A. Walid, and E. P. Putra. (2020). Pengaruh Sampah Rumah Tangga Terhadap Kulitas pH Air Tempat Pembuangan Akhir TPA Air Sebakul Kelurahan Sukarami Kecamatan Selebar Kota Bengkulu. Manhaj: Jurnal Penelitian dan Pengabdian Masyaakat. 9(1) . 37-44. https://ejournal.iainbengkulu.ac.id/index.php/manhaj.

[18] Pemerintah Pusat. (2021). Salinan Peraturan Pemerintah (PP) No. 22 Tahun 2021 Tentang Penyelenggaraan Perlindungan dan Pengelolaan Lingkungan Hidup. Jakarta: Kementerian Sekretariat Negara Republik Indonesia Deputi Perundang-undangan dan Administrasi Hukum. https://peraturan.bpk.go.id/Home/Details/161852/pp-no-22-tahun-2021. diakses: 27 Juli 2021

[19] Putri, W.A., A. I. S. Purwiyanto,. Fauziyah, F. Agustriani, and Y. Suteja. (2019). Kondisi Nitrat, Nitrit, Amonia, Fosfat dan BOD di Muara Sungai Banyuasin, Sumatera Selatan. J. Ilmu dan Teknol. Kelaut. Trop., 11(1), 65-74, doi: 10.29244/jitkt.v11i1.18861.

[20] Mishra. R. and D. Singh,. (2020) Impact of Pollution on Kelo River of Raigarh District," Mater. Today Proc., 29, 310-315, doi: 10.1016/j.matpr.2020.07.280.

[21] Alfaroby. M.A.R and E. Wardhani (2021). Perencanaan Sistem Pengolahan Air Limbah Domestik Pada Daerah Aliran Sungai Cibabat, Kota Cimahi. J. Serambi Eng., 6 (2) doi: 10.32672/jse.v6i2.2884. 